\title{
A Quantitative Synthesis of the Efficacy and Profitability of Conventional and Biological Fungicides for Botrytis Fruit Rot Management on Strawberry in Florida
}

\author{
Leandro G. Cordova, ${ }^{1}$ Felipe Dalla Lana, ${ }^{2}$ Pierce A. Paul, ${ }^{2}$ and Natalia A. Peres ${ }^{1, \dagger}$ \\ ${ }^{1}$ University of Florida, Gulf Coast Research and Education Center, Wimauma, FL, 33598 \\ ${ }^{2}$ Department of Plant Pathology, The Ohio State University, Wooster, OH 44691
}

Abstract

\begin{abstract}
Botrytis fruit rot (BFR) is a major disease that affects strawberry production in Florida and worldwide. BFR management relies on frequent fungicide applications. A meta-analysis was conducted on the outcomes from nine field trials to evaluate the efficacy and profitability of conventional and biological fungicides compared with a nontreated control (NTC). All trials were conducted in Florida between the 2005/06 and 2016/17 growing seasons. Fungicide treatments were applied weekly, and plots were harvested twice a week for yield and BFR incidence quantification. Treatments were grouped into four categories: NTC, multisite only (Thiram), Standard (captan alternated with fludioxonil + cyprodinil), and Bacillus. Following primary analyses, a random effects network meta-analytical model was fitted to estimate the mean yield and BFR incidence responses for each treatment group and to compare means between pairs of groups. The Thiram and the Standard treatment groups
\end{abstract}

increased yield by 378.8 and $502.2 \mathrm{~kg} / \mathrm{ha} /$ week, respectively, compared with the NTC. The yield difference between Bacillus and NTC was not statistically significant. Besides increasing yield, Thiram and Standard also reduced BFR incidence by approximately $10 \%$ compared with the NTC. The mean yield responses and among-study variability from the meta-analysis were used to estimate the probability of a given yield response in a new future trial. The Standard and Thiram treatment groups showed higher estimated probabilities of increasing yield and resulting in a profitable return on application investments than the Bacillus group of treatments. The results from this study provide growers with information that will aid their decision-making process regarding BFR management.

Keywords: fungi, small fruits, disease management, chemicals, yield loss and economic impacts
Botrytis cinerea is the causal agent of Botrytis fruit rot of strawberry (BFR), a major disease that affects strawberry production in Florida and in many other strawberry growing areas (Sutton 1998). In Florida, environmental conditions conducive for BFR development such as temperatures ranging from 15 to $25^{\circ} \mathrm{C}$ during a minimum of $13 \mathrm{~h}$ of continuous leaf wetness are not uncommon during the growing season (Bulger et al. 1987; Mertely et al. 2018). Under such conditions, severe yield losses may occur even in well-managed fields (Legard et al. 2001).

$B$. cinerea inoculum is primarily introduced into Florida strawberry fields via quiescently infected transplants originating from nurseries in Canada and the northern United States (Oliveira et al. 2017). The fungus colonizes senescent leaf tissues and produces conidia that are eventually dispersed by wind, water-splash, and handling operations. Under favorable conditions, conidia germinate and infect petioles, leaves, flowers, and fruits (Braun and Sutton 1987; Mertely et al. 2018; Sutton 1998). Fruit infections usually start at flowering, because flowers are the most susceptible organs (Bristow et al. 1986; Mertely et al. 2002; Sutton 1998). Infected fruits typically develop large brown lesions, usually at the stem end. Under free moisture conditions, the fungus sporulates, covering the lesions with masses of grayish conidia and conidiophores. Diseased fruits, also referred to as gray mold because of the characteristic signs and symptoms, are unmarketable and serve as an important source of secondary inoculum (Mertely et al. 2018; Sosa-Alvarez et al. 1995).

There is great variability in susceptibility among cultivars, with the less susceptible ones having an open canopy architecture or blooming peaks during periods not favorable for disease development.

${ }^{\dagger}$ Corresponding author: N. A. Peres; nperes@ufl.edu

The author(s) declare no conflict of interest.

Accepted for publication 23 May 2019.

(C) 2019 The American Phytopathological Society
However, the more tolerant cultivars may not have all the desirable agronomic and market traits. (Legard et al. 2000; Seijo et al. 2008). Cultural practices such as wider planting spacing and sanitation have been tested as strategies to suppress BFR. However, the possibility of negatively affecting yield without reducing BFR diminishes the adoption of these strategies (Legard et al. 2000; Mertely et al. 2000).

Management of BFR in Florida strongly relies on fungicide applications carried out on a calendar basis with multisite fungicides (e.g., captan or thiram) applied weekly. If weather conditions favor BFR development during peak bloom, a site-specific fungicide (e.g., fenhexamid, cyprodinil + fludioxonil, pyraclostrobin + fluopyram, pyraclostrobin + fluxapyroxad, or isofetamid) is used instead (Legard et al. 2001; Mertely et al. 2018; Whitaker et al. 2017). Calendarbased fungicide programs are gradually being replaced by the Strawberry Advisory System (StAS) (Pavan et al. 2009). This system consists of a web-based decision support tool that times fungicide applications based on a prediction model developed by Bulger et al. (1987). Cordova et al. (2017a, 2017b) showed that when the StAS was used, the number of fungicide applications was reduced by approximately $50 \%$ without compromising yield or BFR management.

Strategies to reduce the number of fungicide applications are essential not only to decrease costs and chemical inputs but also to aid fungicide resistance management. Oliveira et al. (2017) showed that isolates of $B$. cinerea introduced into Florida strawberry fields via transplants were resistant to several of the fungicides labeled for BFR management. Amiri et al. (2013) reported that B. cinerea isolates collected from 2010 to 2012 in Florida had resistance frequencies of $85.4,86.5,44.4,52.7$, and $59.5 \%$ to boscalid, pyraclostrobin, fenhexamid, cyprodinil, and pyrimethanil, respectively. Therefore, BFR management strategies with fewer fungicide applications and rotation of modes of action are necessary to reduce the selection of $B$. cinerea-resistant populations.

Fungicides with multiple or different modes of action from those currently labeled for BFR management in Florida are needed. Biological agents such as Bacillus spp. act in distinct ways compared with conventional fungicides; they may act by antibiosis, parasitism, 
or induced systemic resistance (Bargabus et al. 2002; Jacobsen and Backman 1993). In addition to the practical use, biological agents have more marketing and social appeal than the current conventional fungicides used to control BFR and other diseases. However, studies regarding the effectiveness and profitability of biological agents for managing BFR are necessary before recommending their incorporation into current management programs.

Therefore, the objectives of this study were (i) to determine the effectiveness of Bacillus spp. and a multisite conventional fungicide against BFR compared with a standard fungicide program and a nontreated control and (ii) to estimate the profitability of the treatments tested. To accomplish these objectives, multivariate meta-analytical models (Madden and Paul 2011; Madden et al. 2016; Paul et al. 2008,2011 ) were fitted to data from nine field trials conducted from 2005 to 2017 in Florida, and overall mean differences in yield and BFR incidence were estimated as measures of efficacy. Outputs from the analyses were then used to estimate probabilities of profitable returns on treatment investment for multiple application cost $\times$ strawberry price scenarios.

\section{Materials and Methods}

Experiment design and data collection. Nine fungicide efficacy field trials were conducted during nine strawberry seasons from 2005/06 to 2016/17 (except 2006/07, 2008/09, and 2010/11) in Florida. Trials were carried out either at the University of Florida Gulf Coast Research and Education Center located in Wimauma (2005/ 06, 2007/08, 2009/10, 2011/12, and 2012/13) or in a commercial field in Plant City, FL (2013/14 to 2016/17). Five BFR-susceptible cultivars were used: Sweet Charlie in 2005/06 and 2009/10, Strawberry Festival in 2007/08, Camino Real in 2011/12, Winter Star in 2012/13, and

Radiance from 2013/14 to 2016/17.

Each experiment started with field preparation in late August by raising and covering beds with black plastic mulch. During mulching, beds were fumigated to manage weeds and soil-borne pathogens. Beds were $0.7 \mathrm{~m}$ wide on 1.2-m centers and contained two staggered rows of plants. Bare-root transplants were planted in early October and overhead irrigated for approximately 10 days to facilitate plant establishment. Further irrigation and fertilization were done through drip tapes. Additional operations other than BFR management followed local production standards (Whitaker et al. 2017).

In all the experiments, treatments were arranged in a randomized complete block design, with four blocks in adjacent beds. Plots (experimental units) consisted of 12 to 14 plants each, to which treatments were randomly assigned. A nontreated control (NTC), a standard fungicide program, and nine other fungicides were tested throughout the study. The specific fungicide treatments varied from trial to trial regarding their trade names, but they can be grouped into four groups based on their active ingredient (NTC, Standard, Bacillus, and Thiram) (Table 1).

The Standard group consisted of weekly applications of the active ingredient captan regardless of crop growth stage, except when flowers were present during periods favorable for $B$. cinerea infection $(15$ to $25^{\circ} \mathrm{C}$ and $13 \mathrm{~h}$ of continuous leaf wetness), when fludioxonil + cyprodinil was applied. The Bacillus group was composed of biological treatments applied weekly with either Bacillus amyloliquefaciens, B. pumilus, or B. subtilis as their single active ingredient. Those Bacillus spp. were grouped together because preliminary analysis of variance of individual studies did not show significant

Table 1. Treatment group description with fungicide brand names, season, strawberry field location, number of harvests, and number of fungicide applications conducted on each of the nine trials

\begin{tabular}{|c|c|c|c|c|c|c|c|}
\hline $\begin{array}{l}\text { Treatment } \\
\text { groupa }^{\mathbf{a}}\end{array}$ & Active ingredient & $\begin{array}{l}\text { Brand name and } \\
\text { formulation }^{\mathrm{b}}\end{array}$ & Season & Location & $\begin{array}{c}\text { Number of } \\
\text { applications }\end{array}$ & $\begin{array}{c}\text { Number of } \\
\text { harvests (weeks) }\end{array}$ & Trial \\
\hline \multirow{9}{*}{$\begin{array}{l}\text { Nontreated } \\
\text { control }\end{array}$} & Not applicable & Not applicable & $2005 / 06$ & Wimauma, FL & $\ldots$ & $23(12)$ & 1 \\
\hline & & & $2007 / 08$ & Wimauma, FL & $\ldots$ & $20(11)$ & 2 \\
\hline & & & $2009 / 10$ & Wimauma, FL & $\ldots$ & $16(9)$ & 3 \\
\hline & & & $2011 / 12$ & Wimauma, FL & $\ldots$ & $21(11)$ & 4 \\
\hline & & & $2012 / 13$ & Wimauma, FL & $\ldots$ & $23(12)$ & 5 \\
\hline & & & $2013 / 14$ & Plant City, FL & $\ldots$ & $26(13)$ & 6 \\
\hline & & & $2014 / 15$ & Plant City, FL & $\ldots$ & $23(12)$ & 7 \\
\hline & & & $2015 / 16$ & Plant City, FL & $\ldots$ & $25(14)$ & 8 \\
\hline & & & $2016 / 17$ & Plant City, FL & $\ldots$ & $25(14)$ & 9 \\
\hline \multirow[t]{5}{*}{ Standard } & $\begin{array}{l}\text { Captan / fludioxonil + } \\
\text { cyprodinil }\end{array}$ & $\begin{array}{r}\text { Captan 80WDG / } \\
\text { Switch 62.5WG }\end{array}$ & $2012 / 13$ & Wimauma, FL & $4 / 5$ & $23(12)$ & 5 \\
\hline & & & $2013 / 14$ & Plant City, FL & $8 / 7$ & $26(13)$ & 6 \\
\hline & & & $2014 / 15$ & Plant City, FL & $8 / 6$ & $23(12)$ & 7 \\
\hline & & & $2015 / 16$ & Plant City, FL & $10 / 5$ & $25(14)$ & 8 \\
\hline & & & $2016 / 17$ & Plant City, FL & $10 / 5$ & $25(14)$ & 9 \\
\hline \multirow[t]{7}{*}{ Thiram } & Thiram & Thiram Granuflo 75WDG & $2005 / 06$ & Wimauma, FL & 12 & $23(12)$ & 1 \\
\hline & & Thiram Granuflo 75WDG & $2007 / 08$ & Wimauma, FL & 12 & $20(11)$ & 2 \\
\hline & & Thiram Granuflo 75WDG & $2009 / 10$ & Wimauma, FL & 10 & $16(9)$ & 3 \\
\hline & & Thiram Granuflo 75WDG & $2011 / 12$ & Wimauma, FL & 11 & $21(11)$ & 4 \\
\hline & & Thiram 24/7 & $2014 / 15$ & Plant City, FL & 14 & $23(12)$ & 7 \\
\hline & & Thiram 24/7 & $2015 / 16$ & Plant City, FL & 15 & $25(14)$ & 8 \\
\hline & & Thiram 24/7 & $2016 / 17$ & Plant City, FL & 15 & $25(14)$ & 9 \\
\hline \multirow[t]{8}{*}{ Bacillus } & B. pumilus & Sonata & $2005 / 06$ & Wimauma, FL & 12 & $23(12)$ & 1 \\
\hline & B. amyloliquefaciens & Double Nickel & $2014 / 15$ & Plant City, FL & 14 & $23(12)$ & 7 \\
\hline & B. subtilis & Serenade Max & $2005 / 06$ & Wimauma, FL & 12 & $23(12)$ & 1 \\
\hline & B. subtilis & Serenade Max & $2012 / 13$ & Wimauma, FL & 8 & $23(12)$ & 5 \\
\hline & B. subtilis & Serenade Optimum & $2013 / 14$ & Plant City, FL & 14 & $26(13)$ & 6 \\
\hline & B. subtilis & Serenade Optimum & $2014 / 15$ & Plant City, FL & 14 & $23(12)$ & 7 \\
\hline & B. subtilis & Serenade Optimum & $2015 / 16$ & Plant City, FL & 15 & $25(14)$ & 8 \\
\hline & B. subtilis & Companion & $2015 / 16$ & Plant City, FL & 15 & $25(14)$ & 8 \\
\hline
\end{tabular}

\footnotetext{
${ }^{a}$ Treatments were grouped according to the similarities of their active ingredient.

${ }^{\mathrm{b}}$ Brand name and formulation of the fungicide used on each individual trial.

${ }^{\mathrm{c}}$ Number of times each active ingredient was applied during an individual trial

${ }^{\mathrm{d}}$ Number of times and weeks that fruit were harvested in each individual trial.
} 
differences among them and because of their similar mode of action. The Thiram group corresponded to those treatments in which the multisite fungicide thiram was applied weekly. The specific commercial fungicides used on each trial are listed in Table 1.

Treatment applications were made weekly from mid-December to early March in the experiments conducted at Wimauma (eight to 12 applications) and from late November to early March in Plant City (14 to 15 applications). Treatments were applied with a $\mathrm{CO}_{2}$ backpack sprayer, calibrated to deliver 935.4 liters/ha at $413.7 \mathrm{kpa}$ through a boom mounted with two hollow-cone T-Jet 8002 nozzles.

In all the experiments, plots were harvested twice a week from December to March. The number of harvests per season ranged from 20 to 26, except season 2009/10 with 16 harvests (Table 1). After each harvest, fruits from every plot were counted and classified as marketable or BFR affected. Fruits weighing more than $12 \mathrm{~g}$ and with no apparent disease signs or symptoms were considered marketable, whereas fruits with at least one BFR lesion were counted as BFR affected. Marketable fruits were weighed to determine yield, and BFR incidence was estimated as the number of BFR-affected fruits divided by total number of fruits. The weight of total marketable fruits per trial was divided by the number of weeks of harvesting in that trial, to account for the different number of weeks or harvesting per trial, and reported as kilograms per hectare per week.

Meta-analysis of fungicide effect on yield and BFR incidence. Two-stage network meta-analysis was performed on yield and BFR incidence data, following the methodology described by Madden et al. (2016). In the first stage of the analysis, treatments were grouped based on their active ingredient (Table 1), hereafter referred to by treatment group. The experimental design was considered as a generalized randomized block design, to account for the unbalanced number of experimental units per treatment group per block. Each individual experiment and response variable (yield and BFR incidence) was analyzed separately by fitting linear mixed models with treatment group as fixed and block as random effects using the PROC MIXED procedure in SAS software. To obtain the estimated least square means for yield and BFR incidence for each treatment group (LS means), the lsmeans statement in PROC MIXED was used.

In the second stage, LS means for each treatment group in each individual trial were then used in an unconditional network metaanalysis, considering trial as a random effect, second-order multiplicative structure, and using maximum likelihood to estimate model parameters (model R5 of Madden et al. 2016). Mean difference in marketable yield (YieldD) and BFR incidence (BFRD) for the four treatment groups relative to the baseline NTC, and their respective standard error, confidence interval, and level of significance, were estimated by estimate statements in PROC MIXED. Contrasts were also used to compare means between treatment groups.

Yield projection and risk analysis. Growers and decisionmakers are interested in knowing the chance or likelihood of a given fungicide program resulting in yield increases and profitability, as well as their magnitude. To estimate the probability of a certain treatment group mean being higher than the NTC, we used the estimated mean yield difference YieldD and between-trial standard deviation $\left(\hat{\sigma}_{D}\right)$ from the meta-analysis. As described by Paul et al. (2008), $\hat{\sigma}_{D}$ can be calculated based on the variance-covariance matrix, using the following equation:

$$
\hat{\sigma}_{D}=\sqrt{\hat{\sigma}_{T G}^{2}+\hat{\sigma}_{N T C}^{2}-2 \hat{\sigma}_{T G, N T C}}
$$

where $\hat{\sigma}_{\mathrm{TG}}^{2}$ is the estimated variance of a treatment group, $\hat{\sigma}_{\mathrm{NTC}}^{2}$ is the variance of the NTC, and $2 \hat{\sigma}_{\mathrm{TG}, \mathrm{NTC}}$ is the covariance between the treatment group and NTC (Paul et al. 2008). The probabilities of YieldD being greater than a given constant $(C)$ is given by the following equation:

$$
\mathrm{P}_{+}^{c}=\Phi\left(\frac{C-\text { YieldD }}{\hat{\sigma}_{D}}\right)
$$

where $\Phi($.$) is the cumulative standard-normal function (Paul et al.$ 2008; Sylvester et al. 2018), and the other terms are as defined above.
The probability of yield increasing (YieldD be greater than $C$ ) was calculated for each treatment group, ranging from 0 to $2,500 \mathrm{~kg} / \mathrm{ha}$. Using the values of $C$ and strawberry prices that represent scenarios with low $(\$ 2.00 / \mathrm{kg})$, medium $(\$ 5.00 / \mathrm{kg})$, and high $(\$ 7.00 / \mathrm{kg})$ crop value, we calculated the probability of profitability by the use of the treatment groups in comparison with not using any pesticide (NTC). The range of profitability calculated ranged from $\$ 0$ to $\$ 4,500 /$ week.

\section{Results}

Fungicide effect on BFR incidence. Across the nine trials, the incidence of BFR for the NTC ranged from 1.9 to $26.6 \%$, with a median of $5.4 \%$. For the Standard treatment group, incidence ranged from 1.2 to $8.4 \%$, with a median of $2.5 \%$. The Thiram treatment group had a median disease incidence of $1.5 \%$ and values ranging from 0.5 to $12.6 \%$. For the Bacillus treatment group, BFR incidence ranged from 4.2 to $28.6 \%$, and the median was $4.8 \%$ (Fig. 1A).

BFRD was significantly different from zero for all treatment groups contrasted with the NTC, indicating a significant reduction of BFR incidence in comparison with the NTC. However, the magnitude of the effect was greater for conventional fungicide groups than for the biological control group. For instance, on a percentage scale, BFRD for the Standard and Thiram treatment groups contrasted with the NTC were $-9.79 \%(P<0.0001)$ and $-9.98 \%(P<$ 0.0001 ), with confidence limits of -13.95 to $-5.64 \%$ and -13.33 to $-6.65 \%$, respectively. The BFRD for Bacillus versus NTC was $-3.5 \%(P=0.047)$, with a confidence limit of -6.97 to $-0.046 \%$. The BFRD for Standard versus Thiram was not statistically significant $(P=0.912)$. Both conventional fungicide treatment groups were significantly more effective in reducing BFR incidence than the $\mathrm{Ba}$ cillus treatment group, with an estimated BFRD of approximately $-6.5 \%$ (Table 2).

Fungicide effect on yield. Mean weekly yield of marketable fruit ranged from 676.9 to $2,833.5 \mathrm{~kg} / \mathrm{ha} /$ week for the NTC, with a median of $1,652.5 \mathrm{~kg} / \mathrm{ha} /$ week. The median for the Standard treatment group was $2,411.2 \mathrm{~kg} / \mathrm{ha} /$ week, with a range of $2,034.2$ to $2,712.5 \mathrm{~kg} / \mathrm{ha} /$ week. A numerically lower median was observed for the Thiram treatment group $(1,880.6 \mathrm{~kg} / \mathrm{ha} /$ week $)$, with yield ranging from $1,029.8$ to $3,073.0 \mathrm{~kg} / \mathrm{ha} /$ week. The Bacillus treatment group had a similar median to the NTC $(1,859.0 \mathrm{~kg} / \mathrm{ha} /$ week $)$, although with a narrower range (1,243.7 to $2,422.5 \mathrm{~kg} / \mathrm{ha} /$ week) (Fig. 1B).

Results from the network meta-analysis indicated that compared with the NTC, YieldD was significantly different from zero only for the Standard and Thiram treatment groups, with estimates of $502.2(P=0.0004)$ and $378.8 \mathrm{~kg} / \mathrm{ha} /$ week $(P<0.0001)$ and confidence intervals from 225.5 to 778.9 and from 202.4 to $555.3 \mathrm{~kg} /$ $\mathrm{ha} /$ week, respectively. YieldD was not statistically significant for differences between Bacillus and NTC $(-9.64 \mathrm{~kg} / \mathrm{ha} / \mathrm{week}, P=0.888)$ or between Standard and Thiram $(123.4 \mathrm{~kg} / \mathrm{ha} /$ week, $P=0.4432)$ (Table 2).

Yield projection and risk analysis. The Thiram group had a $61.2 \%$ chance of increasing yield to at least $150 \mathrm{~kg} / \mathrm{ha} / \mathrm{week}$, decreasing to a $50 \%$ chance for a projected yield increase of $378 \mathrm{~kg} / \mathrm{ha} /$ week (Fig. 2A). The Standard group, however, had even higher chances of yield increase compared with the Thiram group. For instance, it had $70.8 \%$ and $50 \%$ likelihood of reaching a weekly yield increase of 150 and $502 \mathrm{~kg} /$ ha relative to the NTC, respectively. The Bacillus group was the only group that did not show probabilities $>0.5$ of yield increasing; as a comparison, the likelihood of having an increase of $150 \mathrm{~kg} / \mathrm{ha} /$ week was only $43 \%$.

Similar trends were observed in all the analyses of profitability of application. In the scenario with low strawberry price $(\$ 2 / \mathrm{kg})$, the Standard group showed $50 \%$ likelihood of having a profit of at least $\$ 1,000 /$ ha/week (Fig. 2B). However, the Thiram group, under the same scenario, had a $50 \%$ chance of reaching a return of $\$ 720 / \mathrm{ha} /$ week. In the second scenario, with fruit at $\$ 5 / \mathrm{kg}$, the application of Standard or Thiram group resulted in more than $50 \%$ chance of having a profit above $\$ 1,800 / \mathrm{ha} /$ week (Fig. $2 \mathrm{C}$ ). In the simulation with the highest strawberry price $(\$ 8 / \mathrm{kg})$, the chances of profitability above $\$ 2,500 /$ ha/week for Standard and Thiram were 61 and $52 \%$, 
respectively (Fig. 2D). Under any of the scenarios tested, the Bacillus group never showed a likelihood above $50 \%$. For instance, the chances having a profit above $\$ 500 /$ ha/week using the Bacillus group were 38,46 , and $47 \%$ for the low, medium, and high crop value scenarios, respectively. Therefore, the chances of reaching even a relatively small profit were smaller than the chances of not reaching it.

\section{Discussion}

BFR is one of the main diseases for both organic and conventional strawberry growers in Florida and worldwide (Mertely et al. 2018; Sutton 1998). The use of fungicides has been the most reliable management strategy deployed by Florida growers with calendar-based fungicide programs adding up to 24 applications per season (Legard

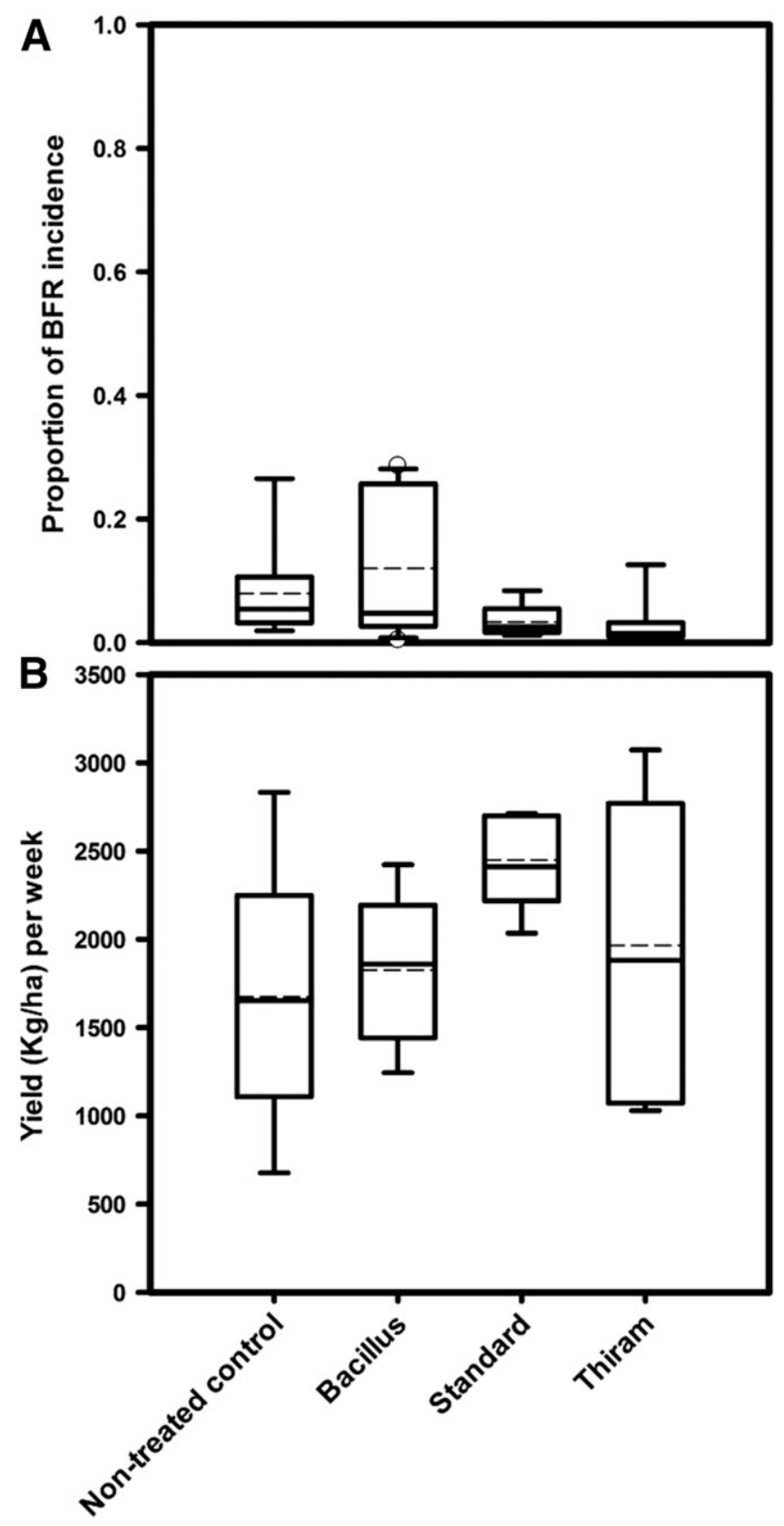

Fig. 1. Box plots of Botrytis fruit rot incidence $(\mathbf{A})$ and yield $(\mathbf{B})$ of strawberry plants treated with three different fungicide programs. The Bacillus group was treated with weekly applications of Bacillus formulations; Thiram treatments were weekly applied with the active ingredient thiram; and the Standard group was treated weekly with captan in the absence of flowers and with applications of fludioxonil + cyprodinil if flowers were present during periods favorable for Botrytis cinerea infection. The 75th and 25th percentiles of the data are respectively represented by the top and bottom lines of the boxes. The average and median are represented by the dashed and solid lines inside the boxes. Outliers are represented by the empty circles. et al. 2001). The high number of fungicide applications coupled with inherent $B$. cinerea characteristics such as its short and polycyclic disease cycle, abundant sporulation, and high genetic variability make this a classic example of a pathosystem at high risk for fungicide resistance development (Fernández-Ortuño et al. 2012; Veloukas et al. 2014). Several studies have been published reporting $B$. cinerea populations resistant to different classes of fungicides (Amiri et al. 2013; Baggio et al. 2018; Fernández-Ortuño et al. 2014; Grabke et al. 2013; Oliveira et al. 2017). Thus, there is a need for incorporating different modes of action that may help mitigate the selection of resistant $B$. cinerea populations. Multisite fungicides are not easily overcome by mutations that confer resistance to pathogens, and their incorporation into current BFR management programs may delay resistance selection (Brent and Hollomon 1995; Deising et al. 2008).

In this study, the effects of conventional (thiram) and biological (Bacillus spp.) multisite fungicides on BFR management and marketable yield were compared with a standard fungicide program and a NTC. The meta-analysis of the outcomes of nine field trials shows that Thiram was just as effective as the Standard treatment group, providing comparable BFR suppression and yield increase relative to the NTC. Although the Bacillus treatment group reduced BFR incidence compared with the NTC, it was less effective than the Standard and Thiram treatment groups and did not provide yield benefit relative to the NTC.

The mean yield differences were used together with the estimated among-study variance from the meta-analysis to estimate probabilities of future outcomes and to assess economic benefits of using a certain fungicide program at different strawberry prices. We used three values of strawberry prices $(\$ 2.00, \$ 5.00$, and $\$ 8.00 / \mathrm{kg})$ in our analysis that represents possible values received by Florida growers based on the USDA National Agricultural Statistics Service database (USDA 2017). Strawberry prices fluctuate considerably within the Florida strawberry season, mainly because the peak production periods and market competition with California and Mexico production, which can drastically increase the market offer and consequently decrease prices.

Yield projection and risk analysis can be used by growers and decision-makers to adjust management strategies throughout the season. These types of analyses have been used by various researchers to estimate whether yield increases brought about by certain fungicide programs were sufficient to offset application costs (Paul et al. 2011; Sylvester et al. 2018; Willyerd et al. 2015). In our study, because of the high value of the crop and relatively low cost of a fungicide application, the likelihood of application costs being offset by yield increases is very high. For instance, considering local application costs of $\$ 64.00$ for the Standard, $\$ 42.00$ for the Thiram, and $\$ 82.00 /$ ha for the Bacillus treatment groups, the chances of at least breakeven were respectively $76.7,67.2$, and $47.2 \%$ for strawberry prices of $\$ 2.00 / \mathrm{ha}$; $77.6,67.8$, and $48.5 \%$ for $\$ 5.00 /$ ha; and $77.9,67.9$, and $48.9 \%$ for $\$ 8.00 /$ ha (Fig. 2). For all the strawberry prices $\times$ application costs evaluated, probabilities of offsetting the cost of applying the Bacillus treatment group were all less than 0.5 . The minimal profit expected at 0.5 probability for the Standard and Thiram treatment groups were, respectively, $\$ 1,000$ and $\$ 720 / \mathrm{ha} /$ week, $\$ 2,500$ and $\$ 1,800 / \mathrm{ha} /$ week, and $\$ 4,050$ and $\$ 2,900 /$ ha/week in the three strawberry price scenarios evaluated. This confirms their economic advantage over the Bacillus treatment group (Fig. 2).

The Standard treatment group consisted of weekly fungicide applications. Cyprodinil + fludioxonil was only applied during bloom if weather conditions favored BFR development, and captan was applied otherwise. Captan is a phthalimide with multisite contact activity, whereas cyprodinil and fludioxonil are respectively anilino-pyrimidines and phenylpyrroles with single-site modes of action. The first acts on methionine biosynthesis and the second on mitogen-activated protein histidine kinase in osmotic signal transduction (FRAC 2018). This program has been a standard and effective treatment for BFR management in Florida for decades, and its success strongly relies on the efficacy of the single-site fungicides used (Cordova et al. 2017a; Legard et al. 2001). However, high frequencies $(>50 \%$ ) of cyprodinil-resistant $B$. cinerea populations have 
Table 2. Mean difference of yield (YieldD) and Botrytis fruit rot (BFRD) and corresponding statistics estimated by network meta-analysis of fungicide treatment trials for management of Botrytis fruit rot of strawberry from field trials conducted in Florida from 2005 to 2017

\begin{tabular}{llcrrrr}
\hline Effect size $^{\mathbf{a}}$ & \multicolumn{1}{c}{ Contrast $^{\mathbf{b}}$} & Mean $^{\mathbf{c}}$ & $\mathbf{S E}$ & $\boldsymbol{t}$ value & Pr $>|\boldsymbol{t}|$ & $\mathbf{9 5 \%}$ CI \\
\hline YieldD & Bacillus versus NTC & $\mathbf{- 9 . 6 4}$ & $\mathbf{6 8 . 4 8}$ & $\mathbf{- 0 . 1 4}$ & $\mathbf{0 . 8 8 8}$ & $\mathbf{- 1 4 3 . 8 8} \leftrightarrow \mathbf{1 2 4 . 6 0}$ \\
& Standard versus NTC & 502.25 & 141.16 & 3.56 & 0.0004 & $225.54 \leftrightarrow 778.95$ \\
& Thiram versus NTC & 378.84 & 90.00 & 4.21 & $<0.0001$ & $202.41 \leftrightarrow 555.26$ \\
& Standard versus Thiram & 123.41 & 160.92 & 0.77 & 0.4432 & $-192.04 \leftrightarrow 438.85$ \\
BFRD & Bacillus versus NTC & $\mathbf{- 0 . 0 3 5 1 1}$ & $\mathbf{0 . 0 1 8}$ & $\mathbf{- 1 . 9 9}$ & $\mathbf{0 . 0 4 7 1}$ & $\mathbf{- 0 . 0 6 9 8} \leftrightarrow \mathbf{- 0 . 0 0 0 5}$ \\
& Standard versus NTC & -0.09796 & 0.021 & -4.62 & $<0.0001$ & $-0.1395 \leftrightarrow-0.0564$ \\
& Thiram versus NTC & -0.09987 & 0.017 & -5.86 & $<0.0001$ & $-0.1333 \leftrightarrow-0.0665$ \\
& Standard versus Thiram & 0.001918 & 0.017 & 0.11 & 0.9122 & $-0.0322 \leftrightarrow 0.0360$ \\
& Thiram versus Bacillus & -0.06476 & 0.023 & -2.8 & 0.0051 & $-0.1101 \leftrightarrow-0.0194$ \\
& Standard versus Bacillus & -0.06284 & 0.027 & -2.36 & 0.0185 & $-0.1151 \leftrightarrow-0.0106$ \\
\hline
\end{tabular}

a YieldD and BFRD correspond to the yield and Botrytis fruit rot incidence difference between the fungicide programs tested and the nontreated control (NTC).

${ }^{\mathrm{b}}$ Contrast between fungicide groups and the NTC conducted in the multivariate meta-analysis. The Bacillus group was treated with weekly applications of $\mathrm{Ba}$ cillus formulations; Thiram treatments were applied weekly with the active ingredient thiram; and the Standard group was treated weekly with captan in the absence of flowers and with applications of fludioxonil + cyprodinil if flowers were present during periods favorable for $B$. cinerea infection.

${ }^{c}$ Mean = estimated effect size; SE = standard error of the estimated effect size; $t$ value $=$ the $t$ statistic from the meta-analysis; $\operatorname{Pr}>|t|=$ the probability value or significance level for the effect of treatment in yield and Botrytis fruit rot incidence; and CI = confidence interval.

A

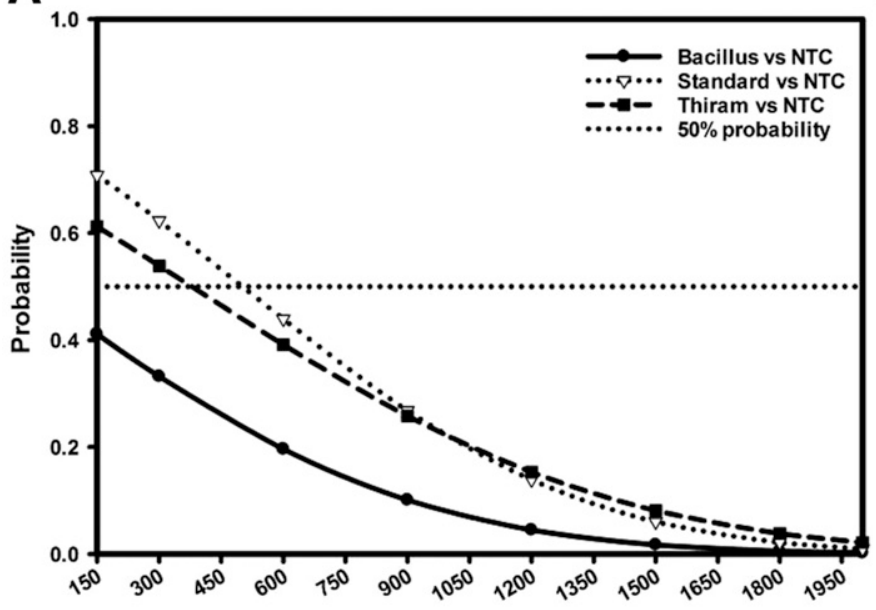

Yield increment relative to NTC (kg/ha/week)

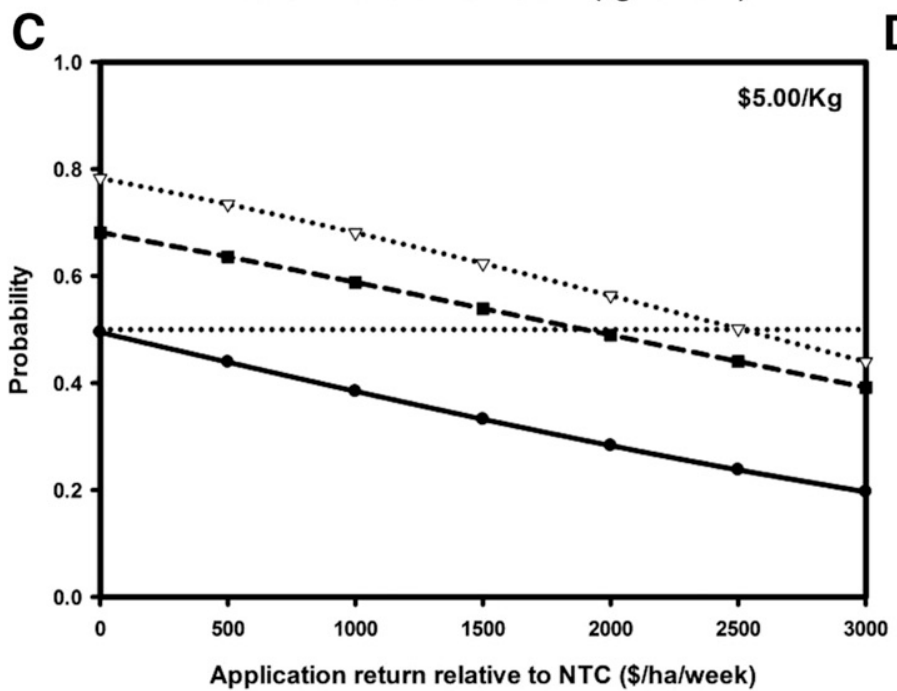

B

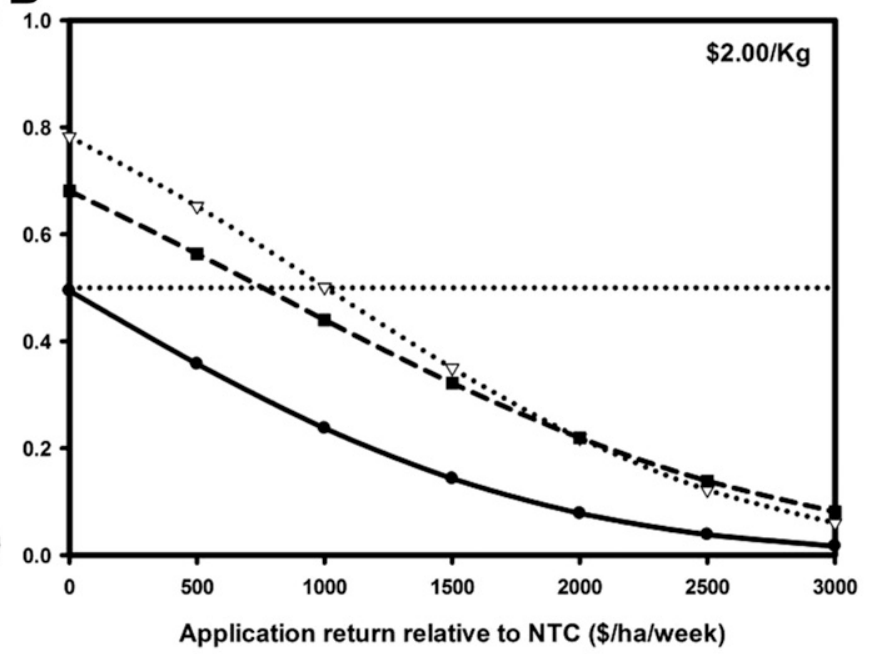

D

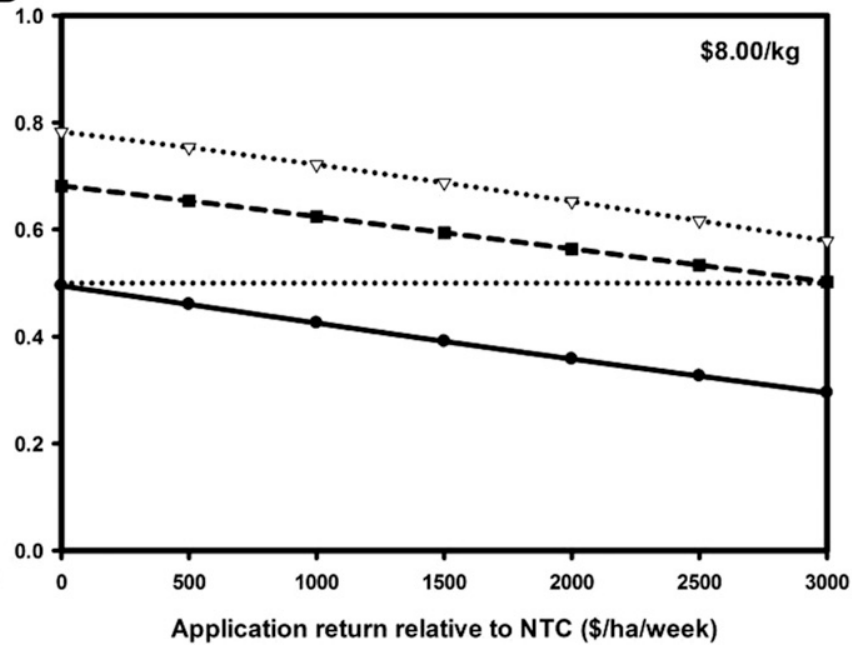

Fig. 2. Estimated probability of fungicide programs resulting in yield increase of 150 to $2,000 \mathrm{~kg} / \mathrm{ha} /$ week relative to the nontreated control (A) and assessment of application return relative to the nontreated control in $\$ /$ ha/week at strawberry prices of $\$ 2.00 / \mathrm{kg}(\mathrm{B}), \$ 5.00 / \mathrm{kg}(\mathrm{C})$, and $\$ 8.00 / \mathrm{kg}$ (D). Probability estimations were based on the mean effect size and among-study variance obtained from the network meta-analysis from nine field trials conducted in Florida from 2005 to 2017 on the management of Botrytis fruit rot of strawberry. Fungicide programs included a nontreated control; Bacillus, which corresponded to weekly applications of Bacillus formulations; Thiram treatments, which were treated weekly with the active ingredient thiram; and the Standard group, which was treated weekly with captan during absence of bloom and with applications of fludioxonil + cyprodinil during bloom and suitable conditions for Botrytis cinerea infection. 
been reported on the southeastern United States. Thus, most of the control efficacy is probably owing to the fludioxonil activity, although populations with reduced sensitivity have been found, including isolates recovered from nursery transplants (Amiri et al. 2013; Fernández-Ortuño et al. 2014; Oliveira et al. 2017). The overuse of standard programs such as described above as well as use of the single-site materials at nurseries might put BFR management at risk, justifying the need for incorporating other multisite fungicides such as thiram and Bacillus spp. into disease management programs.

Thiram (tetramethylthiuram disulfide) acts by contact inhibiting spore germination and mycelial growth. It belongs to the dithiocarbamates and relatives (electrophiles) group (Fungicide Resistance Action Committee [FRAC] code M3) and has been in commercial use since 1925. It is used as seed coating and/or as spray application to protect crops against fungus infection pre- and postharvest (FRAC 2018; Sharma et al. 2003). Here, we quantified the effectiveness of weekly thiram applications for managing $B$. cinerea and increasing yield. Its effectiveness for managing $B$. cinerea in strawberry and other crops (Brook 1956; Cox and Hayslip 1956; Legard et al. 2001; Presley and Maude 1980; Sharma et al. 2003) has been well documented. Because of its multisite mode of action and its similar effectiveness to the Standard treatment group in this study, weekly thiram applications or its incorporation into the Standard program are good alternatives to manage BFR while aiding fungicide resistance management.

Bacillus spp. are currently classified by FRAC as microbial disrupters of pathogen cell membranes (FRAC code 44) (FRAC 2018). However, they may also act by antibiosis, induced systemic host resistance (strains QST713 and FZB24), and lipopeptides production (Jacobsen et al. 2004). The use of biological compounds such as strains of Bacillus spp. to manage strawberry and vegetable diseases has increased in Florida over the past years. Among many factors that may have contributed to this increase, the social interest for a more environmentally sound agriculture, the need for alternative strategies to manage fungicide resistance issues, and the increase of organic production can be listed. For instance, Florida strawberry organic acreage in 2017 almost doubled the 182 acres harvested on 2015 ( Smith and Vallad 2017; USDA 2017). Bacillus spp. effectiveness in inhibiting $B$. cinerea mycelial growth has been reported by Hang et al. (2005) and Toure et al. (2004). Hang et al. (2005) not only reported the effectiveness of the biocontrol agent in vitro but also showed that application of B. subtilis S1-0210 reduced BFR incidence of strawberry in the greenhouse. Similar but not as effective results were found in this study with weekly Bacillus spp. applications; however, no yield benefit was achieved compared with the NTC. Contrary to the study by Hang et al. (2005), our studies were conducted on open fields, a noncontrolled environment with a wide range of microflora interactions that might have prevented the Bacillus treatment group from performing better.

Based on our results, thiram can be recommended as an effective fungicide to be incorporated into programs to manage BFR in Florida. Thiram was not only effective at reducing disease incidence but also showed high probabilities in offsetting application costs and delivering economic benefits, even at relatively low strawberry prices. Besides the biological and economic benefits, the inclusion of a multisite fungicide such as thiram into a program may aid fungicide resistance management, but further studies on the subject are needed. Even though the Bacillus treatment group had low probabilities of bringing economic benefits and did not result in yield increase relative to the NTC, it was effective at reducing BFR incidence compared with the NTC. If manufacturers were able to reduce the cost of Bacillus-based products, they could become a viable alternative to be tankmixed with more effective single-site fungicides and contribute to fungicide resistance management by virtue of their multisite activity. Another application to Bacillus-based products could be its incorporation into strawberry nursery disease management programs. Because fruit yield is not a concern for nurseries, the use of Bacillus spp. could decrease the selection pressure of $B$. cinerea-resistant populations and save the single-site fungicides for use in strawberry commercial fields.

\section{Acknowledgments}

We thank all staff, students, and interns for field assistance collecting data from these trials over the years. We also thank Juliana S. Baggio and Michelle S. Oliveira for their constructive discussions.

\section{Literature Cited}

Amiri, A., Heath, S. M., and Peres, N. A. 2013. Phenotypic characterization of multifungicide resistance in Botrytis cinerea isolates from strawberry fields in Florida. Plant Dis. 97:393-401.

Baggio, J. S., Peres, N. A., and Amorim, L. 2018. Sensitivity of Botrytis cinerea isolates from conventional and organic strawberry fields in Brazil to azoxystrobin, iprodione, pyrimethanil, and thiophanate-methyl. Plant Dis. 102:1803-1810.

Bargabus, R. L., Zidack, N. K., Sherwood, J. E., and Jacobsen, B. J. 2002 Characterisation of systemic resistance in sugar beet elicited by a nonpathogenic, phyllosphere-colonizing Bacillus mycoides, biological control agent. PMPP 61:289-298.

Braun, P. G., and Sutton, J. C. 1987. Inoculum sources of Botrytis cinerea in fruit rot of strawberries in Ontario. Can. J. Plant Pathol. 9:1-5.

Brent, K. J., and Hollomon, D. W. 1995. Fungicide resistance in crop pathogens: How can it be managed? FRAC Monograph No. 1. GIFAP, Brussels, Belgium.

Bristow, P. R., McNicol, R. J., and Williamson, B. 1986. Infection of strawberry flowers by Botrytis cinerea and its relevance to grey mould development. Ann. Appl. Biol. 109:545-554.

Brook, P. J. 1956. Spray experiments to control Botrytis cinerea on tomatoes. N. Z. J. Sci. Technol. A 38:124-128.

Bulger, M., Ellis, M., and Madden, L. 1987. Influence of temperature and wetness duration on infection of strawberry flowers by Botrytis cinerea and disease incidence of fruit originating from infected flowers. Phytopathology 77: $1225-1230$

Cordova, L. G., Amiri, A., and Peres, N. A. 2017a. Effectiveness of fungicide treatments following the Strawberry Advisory System for control of Botrytis fruit rot in Florida. Crop Prot. 100:163-167.

Cordova, L. G., Madden, L. V., Amiri, A., Schnabel, G., and Peres, N. A. 2017b. Meta-analysis of a web-based disease forecast system for control of anthracnose and Botrytis fruit rots of strawberry in southeastern United States. Plant Dis. 101:1910-1917

Cox, R. S., and Hayslip, N. C. 1956. Progress in the control of gray mold of tomato in south Florida. Plant Dis. Rep. 40:718-726.

Deising, H. B., Reimann, S., and Pascholati, S. F. 2008. Mechanisms and significance of fungicide resistance. Braz. J. Microbiol. 39:286-295.

Fernández-Ortuño, D., Chen, F., and Schnabel, G. 2012. Resistance to pyraclostrobin and boscalid in Botrytis cinerea isolates from strawberry fields in the Carolinas. Plant Dis. 96:1198-1203.

Fernández-Ortuño, D., Grabke, A., Bryson, P. K., Amiri, A., Peres, N. A., and Schnabel, G. 2014. Fungicide resistance profiles in Botrytis cinerea from strawberry fields of seven southern U.S. states. Plant Dis. 98:825-833.

Fungicide Resistance Action Committee. 2018. FRAC Code List 2018: Fungicides sorted by mode of action (including FRAC Code numbering). FRAC, CropLife International AISBL, Brussels, Belgium.

Grabke, A., Fernández-Ortuño, D., and Schnabel, G. 2013. Fenhexamid resistance in Botrytis cinerea from strawberry fields in the Carolinas is associated with four target gene mutations. Plant Dis. 97:271-276.

Hang, N. T. T., Oh, S. O., Kim, G. H., Hur, J. S., and Koh, Y. J. 2005. Bacillus subtilis $\mathrm{S} 1-0210$ as a biocontrol agent against Botrytis cinerea in strawberries. Plant Pathol. J. 21:59-63.

Jacobsen, B. J., and Backman, P. A. 1993. Biological and cultural plant disease controls: Alternatives and supplements to chemicals in IPM systems. Plant Dis. 77:311-315.

Jacobsen, B. J., Zidack, N. K., and Larson, B. J. 2004. The role of Bacillus-based biological control agents in integrated pest management systems: Plant diseases. Phytopathology 94:1272-1275.

Legard, D. E., Xiao, C. L., Mertely, J. C., and Chandler, C. K. 2000. Effects of plant spacing and cultivar on incidence of Botrytis fruit rot in annual strawberry. Plant Dis. 84:531-538.

Legard, D. E., Xiao, C. L., Mertely, J. C., and Chandler, C. K. 2001. Management of Botrytis fruit rot in annual winter strawberry using captan, thiram, and iprodione. Plant Dis. 85:31-39.

Madden, L. V., and Paul, P. A. 2011. Meta-analysis for evidence synthesis in plant pathology: An overview. Phytopathology 101:16-30.

Madden, L. V., Piepho, H. P., and Paul, P. A. 2016. Statistical models and methods for network meta-analysis. Phytopathology 106:792-806.

Mertely, J. C., Chandler, C. K., Xiao, C. L., and Legard, D. E. 2000. Comparison of sanitation and fungicides for management of Botrytis fruit rot of strawberry. Plant Dis. 84:1197-1202.

Mertely, J. C., MacKenzie, S. J., and Legard, D. E. 2002. Timing of fungicide applications for Botrytis cinerea based on development stage of strawberry flowers and fruit. Plant Dis. 86:1019-1024.

Mertely, J. C., Oliveira, M. S., and Peres, N. A. 2018. Botrytis fruit rot or gray mold of strawberry. Electronic Data Information Source. PP230. UF/IFAS Extension, Gainesville, FL. 
Oliveira, M. S., Amiri, A., Zuniga, A. I., and Peres, N. A. 2017. Sources of primary inoculum of Botrytis cinerea and their impact on fungicide resistance development in commercial strawberry fields. Plant Dis. 101:1761-1768.

Paul, P. A., Lipps, P. E., Hershman, D. E., McMullen, M. P., Draper, M. A., and Madden, L. V. 2008. Efficacy of triazole-based fungicides for Fusarium head blight and deoxynivalenol control in wheat: A multivariate meta-analysis. Phytopathology 98:999-1011.

Paul, P. A., Madden, L. V., Bradley, C. A., Robertson, A. E., Munkvold, G. P., Shaner, G., Wise, K. A., Malvick, D. K., Allen, T. W., Grybauskas, A., Vincelli, P., and Esker, P. 2011. Meta-analysis of yield response of hybrid field corn to foliar fungicides in the U.S. Corn Belt. Phytopathology 101:1122-1132.

Pavan, W., Fraisse, C. W., Cordova, L. G., and Peres, N. A. 2009. A Web-Based Decision Support Tool for Timing Fungicide Applications in Strawberry. Publication AE450. Florida Cooperative Extension Service, University of Florida, Gainesville, FL.

Presley, A. H., and Maude, R. B. 1980. Control of Botrytis cinerea and Botrytis squamosa in overwintered salad onions by fungicide spray. Ann. Appl. Biol. 94:197-204.

Seijo, T. E., Chandler, C. K., Mertely, J. C., Moyer, C., and Peres, N. A. 2008. Resistance of strawberry cultivars and advanced selections to anthracnose and Botrytis fruit rots. Proc. Fla. State Hort. Soc. 121:246-248.

Sharma, V. K., Aulakh, J. S., and Malik A. K. 2003. Thiram: Degradation, applications and analytical methods. J. Environ. Monit. 5:717-723.

Smith, H. A., and Vallad, G. E. 2017. Biopesticides and alternative disease and pest management products. Pages 373-377 in: Vegetable Production Handbook of Florida. G. E. Vallad, H. A. Smith, P. J. Dittmar, and J. H. Freeman, eds. University of Florida-IFAS Extension, Gainesville, FL.
Sosa-Alvarez, M., Madden, L. V., and Ellis, M. A. 1995. Effects of temperature and wetness duration on sporulation of Botrytis cinerea on strawberry leaf residues. Plant Dis. 79:609-615.

Sutton, J. C. 1998. Botrytis fruit rot (gray mold) and blossom blight. Pages 28-31 in: Compendium of Strawberry Diseases, 3rd Ed. J. L. Maas, ed. American Phytopathological Society, St. Paul, MN.

Sylvester, N. P., Dalla Lana, F., Mehl, H., Collins, A., Paul, P. A., and Kleczewski, N. M. 2018. Evaluating the profitability of foliar fungicide programs in midAtlantic soft-red winter wheat production. Plant Dis. 102:1627-1637.

Toure, Y., Ongena, M. A. R. C., Jacques, P., Guiro, A., and Thonart, P. 2004. Role of lipopeptides produced by Bacillus subtilis GA1 in the reduction of grey mould disease caused by Botrytis cinerea on apple. J. Appl.Microbiol. 96:1151-1160.

United States Department of Agriculture (USDA). 2017. Quick Stats. https:// quickstats.nass.usda.gov. Accessed June 11, 2018.

Veloukas, T., Kalogeropoulou, P., Markoglou, A. N., and Karaoglanidis, G. S. 2014. Fitness and competitive ability of Botrytis cinerea field isolates with dual resistance to SDHI and QoI fungicides, associated with several sdhB and the cytb G143A mutations. Phytopathology 104:347-356.

Whitaker, V. M., Boyd, N. S., Peres, N. A., Noling, J. W., and Renkema, J. 2017. Strawberry production. Pages 293-312 in: Vegetable Production Handbook of Florida. G. E. Vallad, H. A. Smith, P. J. Dittmar, and J. H. Freeman, eds University of Florida-IFAS Extension, Gainesville, FL.

Willyerd, K. T., Bradley, C. A., Chapara, V., Conley, S. P., Esker, P. D., Madden, L. V., Wise, K. A., and Paul, P. A. 2015. Revisiting fungicide-based management guidelines for leaf blotch diseases in soft red winter wheat. Plant Dis. 99:1434-1444. 